\title{
B-cell chronic lymphocytic leukemia
}

INSERM

\section{Source}

INSERM. (1999). Orphanet: an online rare disease and orphan drug data base. B-cell chronic lymphocytic leukemia. ORPHA:67038

B-cell chronic lymphocytic leukemia (B-CLL) is a type of B-cell non-Hodgkin lymphoma (see this term), and the most common form of leukemia in Western countries, affecting elderly adults (mean age of 67 and 72 years) with a slight male predominance (1.7:1), and characterized by a highly variable clinical presentation that can include asymptomatic disease or non-specific B-symptoms such as unintentional weight loss, severe fatigue, fever (without evidence of infection), and night sweats as well as cervical lymphadenopathy, splenomegaly and frequent infections. Some patients can also develop autoimmune complications such as autoimmune hemolytic anemia or immune thrombocytopenia (see these terms). The clinical course is extremely heterogeneous with survival ranging from a few months to several decades. 